Oleksandr Gerasimchuk

Zhytomyr Polytechnic State University, Zhytomyr, Ukraine

E-mail: alex3033@ukr.net

ORCID: https://orcid.org/0000-0002-0304-7555

\title{
Optimization of resource potential of the enterprise on the basis of analysis of the structure of financial resources
}

\begin{abstract}
The subject of research of the scientific article is the optimization of the resource potential of the enterprise based on the analysis of the structure of financial resources. The methodological basis of the study were the provisions of modern economic theory, financial statements of the studied enterprise and scientific works of scientists. The purpose of the study is to analyze the optimization of the components of the resource potential of the enterprise. In the course of the research the estimation of optimization of structure of financial resources of the enterprise on the basis of the multicriteria approach was carried out. It is determined that the total amount of financial resources that is necessary for the researched enterprise - sources of financing is 150000 thousand UAH. Based on the results of calculations of the cost of borrowed capital, taking into account the tax corrector, the weighted average cost of capital was calculated for all 10 alternatives. Given that the company is interested in obtaining a certain amount of financial resources at the lowest weighted average interest rate in the presented models, the best alternatives are 1 and 10 where the weighted average cost of capital is $15.51 \%$. It is concluded that under the terms of the settlement agreement a significant increase in the profitable part of the researched enterprise is planned, taking into account the possibilities in the future, and first of all taking into account the real, for today, state of financial and economic activity of the enterprise. Therefore, the company needs to use a comprehensive approach to managing its financial resources. In the conditions of transformation of market relations forecasting and substantiation of strategy of development of financial and economic activity of the organization taking into account an estimation of dynamics of a market conjuncture and influence of macroeconomic factors of maintenance of conformity of volume and structure of own and involved financial resources (capital). Resources in the process of operational, investment, financial activities of the organization to achieve optimal structure and value of own and borrowed resources from the standpoint of impact on the financial condition of the enterprise and ensure its financial stability, liquidity, solvency minimization of financial resources.
\end{abstract}

\author{
Keywords \\ Resource potential of the \\ enterprise optimization, financial \\ resources, strategy, amicable \\ agreement
}

JEL: L32, L81, G10

DOI: https://doi.org/10.30525/2500-946X/2021-2-1

\section{Introduction}

In a market economy, one of the main factors influencing the scale and pace of development of the enterprise is the volume and structure of its available resource potential.

The main element of the overall management system is the development of resource potential of the enterprise. The efficiency of resource management of the enterprise is realized through its rational use in order to obtain the full end result in the form of production of high quality products and quality servicesthat is, the selection of effective forms of their organization in the enterprise taking into account the conditions and features of its economic activity. Therefore, the comprehensive development of theoretical and practical issues of formation and use of financial resources of the enterprise in modern conditions, as well as identifying ways to improve their efficiency is an urgent problem today. The main prerequisite for promoting the successful development of the enterprise is to increase the efficiency of resource management (Garina, 2016).
In order to increase the efficiency of resource management, it is necessary to develop and implement its own strategy for the company to make qualitative changes in the composition of resources and increase efficiency in their management.

A characteristic feature of effective management of resource potential is, first of all, the evaluation of the effectiveness of the resources of the enterprise, where the useful result of the enterprise is compared with the cost of obtaining this useful result. The useful result can be economic (profit of the enterprise) and social (ensuring a better standard of living for the person). During the management of resource potential it is necessary to implement optimization, ie the selection of effective forms of their organization in the enterprise taking into account the conditions and features of its economic activity. Thus, the research problem is stated as follows: optimizing the efficiency of resource management of the enterprise is important in connection with the rapid rate of consumption of material resources, in contrast to the rate of production and provision of quality services. 
The current paper aims to study optimize the components of the resource potential of the enterprise.

\section{Survey methodology}

The theoretical and methodological basis for the advancement of the current economic theory, financial soundness, science of workers and foreigners and economics in the field of optimizing warehouse storage in the minds of rinkovyh vidnosin. For reaching the level of awareness of victorious advances methods: use - for the definition and interpretation of theoretical dzherel from the previous problem; analysis and synthesis - for the identification of prospects for the development of the process of forming, distributing and reducing the resource potential; systemic reason, how to become theoretically and methodologically based on the functional and statistical model of pre-sentient processes, in addition, the method of analysis, the method of synthesis, the method of formalization.

A large number of scientists have studied the main aspects of the resource potential of the enterprise and the signs of effective management, namely: O. Arefieva, Y. Vorobyova, S. Ishchuk, N. Krasnokutskaya, V. Novitsky. A significant contribution to the strategic aspects of the development of resource potential of enterprises was made by foreign scientists, among which we can highlight K. Wernerfelt, P. Romer, R. Solow. And the main problems in assessing the resource potential of enterprises and optimizing the efficiency of resource use were studied by the following scientists: I. Borisova, O. Elozina, N. Caravan, I. Smaga. However, a detailed analysis of scientific and economic sources showed a lack of research to optimize the components of the financial potential of the enterprise.

\section{Model of multicriteria optimization of financial resources}

Resource potential affects all areas of the enterprise and, of course, has always been the object of management. However, the lag of theoretical developments from management practice at the present stage is explained by the rapid emergence of new types of resources, sources of their formation and methods of evaluation.

In a highly competitive business environment, organizations must innovate to maintain their financial performance and achieve competitive advantage. (example, Bagherzadeh et al., 2020; Iglesias et al., 2020; Ind et al., 2017; Markovic, 2016). This is especially true of a pandemic COVID-19, as innovation has long been proposed as one of the most effective strategic responses to crises (Wenzel et al., 2020). However, despite their momentum, innovation can be challenging in times of crisis, as it requires swift and decisive action, often with limited resources (Chesbrough, 2020; Wenzel et al., 2020). Due to limited time and resources in times of crisis, firms are increasingly involved in open innovation from business to business (B2B OI) (Chesbrough, 2020; Dahlander \& Wallin, 2020).

It is known that the resource potential of the enterprise is a system of tangible, intangible, labor, financial resources in order to achieve the strategic goals of the enterprise. Based on this, we will conduct a detailed analysis of the optimal structure of financial resources of the enterprise. Thus, in order to form a model for calculating the optimal structure of financial resources of the enterprise, we used a multi-criteria approach.

There are many $\mathrm{X}$ of all alternative solutions, from which you need to choose the best or optimal solution. In order to be able to choose, the set $\mathrm{X}$ must contain at least two solutions.

In the multicriteria optimization problem, the comparison of solutions is preferably carried out not directly, but with the help of numerical functions given in $\mathrm{X}$, , which are called criteria. We consider it appropriate to determine the criteria for optimizing the sources of financing in relation to the objectives of the policy of financing noncurrent assets. The main purpose of financing policy is to form the required amount of money. Within this goal, it is possible to formulate second-order goals that contribute to the quality of the main goal. Therefore, the goals of the second order are defined as follows: minimization of the term of attraction of sources of financing, minimization of the cost of attraction of sources of financing, conformity of the structure of sources of financing to the target financial structure of capital. Each goal must meet a certain evaluation criterion (Table 1).

Since the main goal of financing policy is the formation of a sufficient amount of funds, the main criterion for optimization is to determine the compliance of funds with the investment needs of the enterprise. Therefore, on the basis of this criterion, it is advisable to carry out a preliminary screening of alternatives.

Minimize time to attract funding sources. Obtaining funding, especially from outside, is a long-term process. Therefore, we can highlight the next important criterion for the effectiveness of fundraising - obtaining funding as soon as possible, ie in the shortest possible time. The peculiarity of this term is that it consists of several time intervals that characterize the hourly parameters of obtaining funding from specific sources.

An important task from the standpoint of funding policy is to minimize the costs associated with obtaining funding. The total cost of obtaining financing is equal to the weighted average cost of capital. It should be the smallest (Gonchar, 2016).

Correspondence of the structure of sources of financing to the target financial structure of capital. For this purpose, such a criterion as the share of equity is chosen. This criterion is directly related to the financial structure of the capital of

TABLE 1 Goals and criteria for optimizing the structure of financial resources of the enterprise

\begin{tabular}{|c|c|c|}
\hline Submission of goals & Goal & Criterion \\
\hline Head goal & 1. Formation of the required amount of money & The total amount of generated sources \\
\hline \multirow{3}{*}{ Objectives of the subordinate order } & 1.1 Minimize time to attract funding sources & Time required to attract sources \\
\hline & 1.2 Minimize the cost of attracting funding sources & The cost of attracting sources \\
\hline & $\begin{array}{l}1.3 \text { Correspondence of the structure of funding sources } \\
\text { to the target financial capital structure }\end{array}$ & The ratio of equity and debt capital \\
\hline
\end{tabular}

Source: developed by the author 
the enterprise. The task of the target capital structure by calculating the structure that has already developed in the enterprise and satisfies it, is the benchmark that must meet the financial structure of the received funding, the purpose of which is not to worsen the existing capital structure of the enterprise.

To solve the formulated problem, the following algorithm for optimizing the structure of financial resources is proposed:

1) the first stage is associated with the formation of all possible alternatives to attract funding;

2) at the second stage the selection of alternatives is carried out, which are not aimed at obtaining funding in the required amount. If after selection there are two or more alternatives, then finding the optimal solution continues;

3 ) at the last stage it is necessary to build an additive value function and choose the alternative with the lowest value (Dunda, 2016).

The proposed model of multi-criteria optimization of the structure of financial resources of the enterprise will promote sound decision-making on the formation of noncurrent assets of the enterprise, which will increase its investment potential.

Solving this problem is important and significant for the company every time there is a process of financial planning. Most often, such a process is carried out at enterprises at the beginning of the new year. Therefore, at least once a year for the company it is advisable to optimize financial resources and determine the most attractive option for financing non-current assets. This task must be preceded by an assessment of financial stability, liquidity, solvency and profitability for the previous stages.

\section{Estimation of optimization of structure of financial resources}

We will evaluate the optimization of the structure of financial resources of the enterprise in accordance with the proposed multi-criteria approach. The total amount of financial resources that is necessary for the study of the enterprise - sources of funding is 150000 thousand UAH. This amount can be distributed between equity and debt in various ways, which are presented in table 2 - various structure of financial resources of the enterprise.

We will note that as of 2020 the total amount of financial resources of the enterprise made 137060 thousand UAH. But in 2021 it is planned to significantly increase the amount of financing of the enterprise.

If the first criterion for optimizing the structure of financial resources is to determine the total amount of funding of UAH 150,000.0 thousand, the second criterion can determine the target capital structure. Therefore, the share of equity must be at least $50 \%$.

It should be noted that the main goal of the researched enterprise is to get $100 \%$ financing, ie by 2022 to provide the total amount of financial resources not less than UAH 150,000 thousand.

For 2021, the planned income tax rate is $18 \%$. The interest rate for the use of borrowed funds is subject to change. The higher the share of short-term and longterm loans, the higher the percentage $(28 \%)$. If you use current liabilities, which have a lower value, the planned rate is $20 \%$.

The calculation of the optimal structure of financial resources of the enterprise is presented in table 2 .

TABLE 2 Calculation of the optimal structure of financial resources of the surveyed enterprise by the criterion of minimizing the weighted average cost of capital

\begin{tabular}{|c|c|c|c|c|c|c|c|c|c|c|}
\hline Indicator name & Option 1 & Option 2 & Option 3 & Option 4 & Option 5 & Option 6 & Option 7 & Option 8 & Option 9 & Option 10 \\
\hline General need for capital & 100 & 100 & 100 & 100 & 100 & 100 & 100 & 100 & 100 & 100 \\
\hline Equity & 0,73 & 0,70 & 0,67 & 0,63 & 0,60 & 0,57 & 0,53 & 0,60 & 0,67 & 0,73 \\
\hline $\begin{array}{l}\text { Capital statements, } \\
\text { including: }\end{array}$ & 0,27 & 0,30 & 0,33 & 0,37 & 0,40 & 0,43 & 0,47 & 0,40 & 0,33 & 0,27 \\
\hline Long term duties & 0,25 & 0,24 & 0,24 & 0,24 & 0,23 & 0,23 & 0,23 & 0,28 & 0,36 & 0,48 \\
\hline Current responsibility & 0,75 & 0,76 & 0,76 & 0,76 & 0,77 & 0,77 & 0,77 & 0,72 & 0,64 & 0,53 \\
\hline $\begin{array}{l}\text { Shoulder of financial } \\
\text { leverage }\end{array}$ & 0,36 & 0,43 & 0,50 & 0,58 & 0,67 & 0,76 & 0,88 & 0,67 & 0,50 & 0,36 \\
\hline Interest rate for a loan & 0,22 & 0,23 & 0,24 & 0,25 & 0,26 & 0,27 & 0,28 & 0,25 & 0,23 & 0,20 \\
\hline Income tax rate & 0,18 & 0,18 & 0,18 & 0,18 & 0,18 & 0,18 & 0,18 & 0,18 & 0,18 & 0,18 \\
\hline Tax corrector & 0,82 & 0,82 & 0,82 & 0,82 & 0,82 & 0,82 & 0,82 & 0,82 & 0,82 & 0,82 \\
\hline $\begin{array}{l}\text { Interest rate on the loan, } \\
\text { taking into account } \\
\text { the tax corrector }\end{array}$ & 0,18 & 0,19 & 0,20 & 0,21 & 0,21 & 0,22 & 0,23 & 0,21 & 0,19 & 0,16 \\
\hline Cost of equity & 18,00 & 18,00 & 18,00 & 18,00 & 18,00 & 18,00 & 18,00 & 18,00 & 18,00 & 18,00 \\
\hline \multicolumn{11}{|l|}{$\begin{array}{l}\text { The price of the constituent } \\
\text { elements of capital: }\end{array}$} \\
\hline Equity & 13,20 & 12,60 & 12,00 & 11,40 & 10,80 & 10,20 & 9,60 & 10,80 & 12,00 & 13,20 \\
\hline borrowed capital & 21,87 & 24,60 & 27,33 & 30,07 & 32,80 & 35,53 & 38,27 & 32,80 & 27,33 & 21,87 \\
\hline $\begin{array}{l}\text { weighted average cost } \\
\text { of capital }\end{array}$ & 15,51 & 16,20 & 17,11 & 18,24 & 19,60 & 21,18 & 22,98 & 19,60 & 17,11 & 15,51 \\
\hline
\end{tabular}

Source: formed on the basic data of the surveyed enterprise 
In Table 2 presents the calculation of the interest rate on the loan, taking into account the tax corrector for all alternatives.

Based on the results of our study, the cost of borrowed capital was calculated taking into account the tax corrector and the weighted average cost of capital for all 10 alternatives was calculated. Given that the company is interested in obtaining a certain amount of financial resources at the lowest weighted average interest rate in the presented models, the best alternatives are 1 and 10 where the weighted average cost of capital is $15.51 \%$.

Under the terms of the settlement agreement, a significant increase in the profitable part of the researched enterprise is planned, taking into account the opportunities in the future, and first of all taking into account the real, for today, state of financial and economic activity of the researched enterprise, namely:

1) Separate structural subdivisions of the investigated enterprise organized outbound trade on the territories of: 235 general military training grounds (Mykolaiv region, Ulyanovka village), 33 general military training grounds (Chernihiv region, Desna township), 37 general military training grounds (Zhytomyr). Perlivka), 233 all-military range (Rivne), 184 training center of the Academy of Land Forces. P. Sagaidachny (Yavoriv), general military range of unit A 1089 (village of Starychi, Lviv region), general military range of unit A 1363 (Novomoskovsk).

Thus, due to outbound trade, the turnover of branches ("Odessa Department of Military Trade", "Zhytomyr Branch", "Lviv Branch", "Voisktorg" branch) for the period 2016-2020 increased by 300\%.

Inflation will increase prices for products and products, with prices rising by an average of $0.08 \%$ each year.

Thus, further cash inflows will increase, including due to inflation.

At the same time, measures are taken to organize the work and logistics of 4 field trade offices in the cities of anti-terrorist operations, namely: provided with postterminals for non-cash payments; registrars of settlement operations are made out; obtained licenses for the right to trade in tobacco products; measures are taken regarding the order of pricing and assortment list of goods; staff selection activities (with a personal medical record) are carried out.

Thus, due to the trade activities of one field office, the revenue side of the surveyed enterprise will increase by approximately UAH 8,640.0 thousand per year, namely:

The amount of the average check per day $\approx$ is UAH 80.0, the average flow of visitors per day is $\approx 300$ people:

$80.0 \times 300$ people. $=\mathrm{UAH} 24,000.0 /$ day;

24,000 x 30 days = UAH 720,000.0 / month;

$720,000.0 \times 4$ branches = UAH 2,880,000.0. income per month.

(UAH 34,560.0 thousand / year).

It should be noted that in the future there is an opportunity to increase revenues from trade and catering by $35 \%$ through the following measures: ensuring commodity coverage of turnover plans by establishing financial support, streamlining the use of proceeds from the sale of goods in retail trade and catering goods and covering the cost of sales, establishing normal settlements with suppliers; organization of high-quality and timely supply of the necessary range of food and non-food products; expansion in the turnover of the segment of military products and ensuring a steady growth trend in the purchase and sale of goods in this group; ensuring the opening of new trade, catering and resumption of previously closed facilities; placement of stationary and mobile outlets on the territory of military units; to improve trade services, accelerate the movement of goods to the consumer and the introduction of methods of off-store sales of goods: (Online stores); increasing the efficiency of the use of space used in trade and catering services; ensuring the availability of lunch products for soldiers' teahouses for catering for servicemen; creation of material and technical base for rendering of exit services (service in the place of the customer). Through advertising in the media, placement of information in specialized catalogs, participation in specialized exhibitions to promote on the market services for the sale of takeaway lunch products, production of highly artistic products to order, the sale of semi-finished products; taking an active part in the tender for the provision of catering services for servicemen of the Armed Forces of Ukraine.

Measures are being taken to ensure the efficient use of space used in trade and catering services by: restoring non-functioning military teahouses (reconstruction, modernization, retrofitting, re-equipment); increase in the assortment list of available soldier's teahouses (increase in everyday goods, increase in the range of tobacco products, increase in hot drinks for the winter period); introduction of soldiers' teahouses in military units with a small number of trade and catering establishments to meet the needs of servicemen and members of their families.

Currently, measures are being taken to effectively use the real estate not involved in the economic activity of the investigated enterprise, namely: search for contractors to provide warehousing services, which in general will bring the company revenue for 10 years in the amount of 85,500 thousand UAH; return to the use of real estate - nonresidential premises with a total area of $12354.9 \mathrm{~m}^{2}$, which in turn will bring the company 1944 thousand UAH. for a year.

Given the above, the company's revenues from the provision of warehousing services and the transfer of part of the area for rent will be:

in 2021: for 83 (23087 sq.m. * $126 \mathrm{UAH} /$ sq.m.) lease agreements - UAH 2,909.00 thousand; for 143 (470342p-m * $35 \mathrm{UAH} / \mathrm{p}-\mathrm{m}$ ) contracts for the provision of warehousing services - 16462.00 thousand UAH;

in 2022: under 87 agreements (23667 sq.m. * $126 \mathrm{UAH} /$ sq.m.) of lease - UAH 2,982.00 thousand; under 161 contracts (412462p-m * 35 UAH / p-m) provision of warehousing services - UAH 17,723.00 thousand;

in 2023: for 95 (24348 sq.m. * $126 \mathrm{UAH} /$ sq.m.) lease agreements - UAH 3,054.00 thousand; for 172 (520228p-m

TABLE 3 Revenue part of the surveyed enterprise

\begin{tabular}{|l|l|l|l|l} 
Institution name & $\begin{array}{c}\text { Average check, } \\
\text { thousand UAH }\end{array}$ & $\begin{array}{c}\text { The flow of visitors, } \\
\text { pers. }\end{array}$ & $\begin{array}{c}\text { Income per day, UAH } \\
\text { Income per month, } \\
\text { UAH. }\end{array}$ & $\begin{array}{c}\text { Income per year, } \\
\text { UAH }\end{array}$ \\
\hline Field office No. 1 & 80,0 & 300 & 24000,0 & 720000,0 \\
\hline Amount & 80,0 & 300 & 24000,0 & 720 \\
\hline
\end{tabular}


* $35 \mathrm{UAH} / \mathrm{p}-\mathrm{m}$ ) contracts for the provision of warehousing services - 18 243,00 thousand UAH;

in 2024: for $98(24714 * 126)$ lease agreements UAH 3,114.00 thousand; for 185 (548800* 35) contracts for the provision of warehousing services - UAH 19,208.00 thousand;

in 2025: for $109(25658 * 126)$ lease agreements UAH 3,233.00 thousand; for $203613200 * 35$ contracts for the provision of warehousing services - UAH 21,462.00 thousand.

If at least $25 \%$ of the above measures are implemented, the researched enterprise will be able to increase the sales of goods (works, services), which in turn will increase the income from the sale of goods, works and services.

\section{Conclusion}

Thus, within the framework of the amicable agreement, the researched enterprise will be able to settle the existing debts and return to the implementation of normal financial and economic activities, and the implementation of strategic defense tasks that are currently facing our State.
The total income from sold goods, works, services of the enterprise in 2021 will be approximately 154378.0 thousand UAH.

Thus, according to the results of the study according to this model, we get an increase in enterprise income from 20 to 25 million UAH. for a year. The researched enterprise needs to use a comprehensive approach to managing its financial resources. In the conditions of transformation of market relations forecasting and substantiation of strategy of development of financial and economic activity of the organization taking into account an estimation of dynamics of a market conjuncture and influence of macroeconomic factors of maintenance of conformity of volume and structure of own and involved financial resources (capital). resources in the process of operational, investment, financial activities of the organization to achieve optimal structure and value of own and borrowed resources from the standpoint of impact on the financial condition of the enterprise and ensure its financial stability, liquidity, solvency minimization of financial resources from various sources (own and borrowed) optimization of the weighted average cost of capital of the organization.

\section{References}

[1] Garina, M. S. Resource management as an element of sustainable development of the business structure. VIII International Student Electronic Scientific Conference "Student Scientific Forum - 2016". E-source: https://scienceforum.ru/2016/article/2016019772

[2] Gonchar, M. V. (2016). Substantiation of structuring the resource potential of the enterprise. Scientific Bulletin of Polissya, 2(6), 108-113.

[3] Dunda, S. P. (2016). Development of the enterprise and assessment of the factors influencing it. Effective Economy, 12. E-source: http://www.economy.nayka.com.ua/?op=1\&z=5329

[4] Bagherzadeh, M., Markovic, S., Cheng, J., \& Vanhaverbeke, W. (2020). How does outside-in open innovation influence innovation performance? Analyzing the mediating roles of knowledge sharing and innovation strategy IEEE Trans. Eng. Manag., 67(3), 740-753.

[5] Chesbrough, H. (2020). To recover faster from Covid-19, open up: managerial implications from an open innovation perspective Ind. Mark. Manag. DOI: https://doi.org/10.1016/j.indmarman.2020.04.010

[6] Dahlander, L., \& Wallin, M. (2020). Why now is the time for "Open Innovation" Harv. Bus. Rev. 08-27.

[7] Iglesias, O., Markovic, S., Bagherzadeh, M., \& Singh, J. J. (2020). Co-creation: A key link between corporate social responsibility, customer trust, and customer loyalty J. Bus. Ethics, 163(1), 151-166.

[8] Ind, N., Iglesias, O., \& Markovic, S. (2017). The co-creation continuum: From tactical market research tool to strategic collaborative innovation method J. Brand Manag., 24(4), 310-321.

[9] Markovic, S. M. (2016). 21st-Century Brands: An Innovation Opportunity and an Ethical Challenge Universitat Ramon Llull, Barcelona, Spain.

[10] Wenzel, M., Stanske, S., \& Lieberman, M. B. (2020). Strategic responses to crisis Strateg. Manag. J. DOI: https://doi.org/10.1002/smj.3161 